DOI: 10.20472/IAC.2018.043.030

\author{
PHUMELELE MSHENGU \\ University of KwaZulu-Natal, South Africa \\ MUHAMMAD HOQUE \\ University of KwaZulu-Natal, South Africa
}

\title{
AN EVALUATION OF TALENT MANAGEMENT WITH THE DEPARTMENT OF ARTS AND CULTURE IN KWAZULU-NATAL, SOUTH AFRICA
}

\begin{abstract}
:
One of the problems faced by today's organisations is the need to stay current and adapt to the evolving environmental, market, economic and workforce conditions. "It has become clear that the most important organisational asset, especially in knowledge intensive organisations depend on its employees". Organisations now have to put more emphasis on recruiting and retaining top performing employees. This has given rise to talent management. The aim of the study was to evaluate talent management at KZN Department of Arts and Culture and the purpose of the study was to: identify if the Departments strategic HR policies are hindering or supporting their talent efforts and to determine what talent management practices should be put in place to in order to attract, develop and retain high performing employees and to get an understanding of how the Departments employees feel about the current state of events. A quantitative study was conducted where an electronic questionnaire was sent to the Arts and Culture employees. The population size of the study was 300 Arts and Culture employees who had e-mail and internet access. Of the 300 employees, a total of 170 responded to the questionnaire giving a $57 \%$ response rate. The main findings of the study were that the Department of Arts and Culture KZN did not have a talent management strategy nor talent management policies. The respondents scored the department low on issues such as promotion, sourcing candidates internally and financial assistance to study further. The Department will need to pay special attention to those items. On the upside, the majority of employees stated that they were the right fit for their positions either by their academic qualification or work experience. This is well and good but certain employees hold qualifications that allow them to be able to perform at higher levels than what they are on currently. There are no policies in place to address this, and currently nothing has been done to find talent within the Department. The Department can introduce programmes such as job rotation, mentoring system, cross training and regular career discussions as a start which can be implemented by the Senior Managers in each Directorate. Policies should be implemented which allow for horizontal movements and internal recruitment since the lack of is one of the main sources of dissatisfaction amongst the Departments employees.
\end{abstract}

\section{Keywords:}

Talent management, organisation, performance, strategy

JEL Classification: D22, J24, L84 